\title{
Egypt, Possible Conflict and Cooperation Areas in the Foreign Policy of the Islamic Republic of Iran
}

\author{
M. Serkan Taflıŏlu \\ Niğde Ömer Halisdemir University, Niğde, Turkey
}

\begin{abstract}
A country's foreign policy process is also a decision-making process. Foreign policy is a rational, multifaceted, and balanced area that needs to be thought and executed. States operate within the framework of the decisions of governments. The decision-making process can change its direction with reflections and influences from national, regional, and international politics. While some theories think that governments/decision-makers are rational actors, there are other theories. Decision-makers/governments are able to make decisions in accordance with national interests. Who or which institution will determine what a country's national interest is and whether its foreign policy is in the national interest. Claiming that a foreign policy carried out by political will is in line with national interest and gives it a certain degree of legitimacy and authority. The main problem here is the identification of national interest with the discourse/policies of those officially responsible for the conduct of foreign policy. National interest can best be determined if it has become a verifiable expression of the priorities of a nation. Heads of state trust their advisors in their immediate surroundings when making foreign policy decisions, so it is important to recognize the composition of the immediate environment. In authoritarian and totalitarian regimes, such as Iran, ideology and leader are vital in foreign policy. The Iranian geopolitics, the ideological structure of the political regime, and the constitutional structure, which is constitutionally effective and superior, should be analyzed in order to examine Iran's foreign policy. This comprehensive assay will naturally exceed the purpose and scope of this study.
\end{abstract}

Keywords: Islamic Republic of Iran, Egypt, foreign policy

\section{Introduction}

Strategies/calculations in the Middle East are not read/implemented as planned on maps/tables/numbers/words. For National Security, power (not just military force) requires rational acquisition and manipulation. One of the main goals in the protection of National Security is to prevent the formation of blocks against yourself in your region by using foreign policy tools. As Iran confronted the post-revolutionary realpolitik realities, it shifted from idealistic discourses to more realist practices. As a result, after Khomeini, Iran tried to normalize its relations with Arab states, especially Saudi Arabia. The geopolitical realities and the goals of Iran's political regime have in recent years changed from an implicit struggle with Arab states to an open conflict. The increasing influence of Iran on Iraq, Syria, Yemen, and Lebanon brought Arab states against Iran. Remove the Gulf Arab states and Turkey, they saw America as a counterbalance to Iran, but in recent

M. Serkan Taflığlu, Dr., associate professor, Department of Political Science and International Relations, Niğde Ömer Halisdemir University, Niğde, Turkey. 
years, the geopolitical fracture Egypt to the forefront as a balancing factor. The aim of our study will be to understand the present situation after considering Iranian-Egyptian relations from a historical perspective. It will be aimed at understanding whether there is a possibility of serious rapprochement and cooperation between Iran and Egypt.

\section{Foreign Policy Objectives of the Islamic Republic of Iran}

When examining the political regimes, if any, the highest norm and the political text start with the constitutions. As the state describes itself, it is also the rules governed by the state itself. One of the main objectives of the Constitution is to bring balance, predictability, and functioning order to the actions of the state. Leaving aside the philosophical and hypothetical debates on the constitution, constitutions can be anti-democratic and authoritarian/totalitarian. The constitution of the Islamic Republic of Iran is one of the best examples of the question of how to establish an authoritarian and totalitarian regime (Taflioğlu, 2010). The constitution of the Iranian constitution states that the revolution will continue inside and outside until the final victory of the oppressed against the oppressors is won. It is emphasized that international cooperation with other Islamic and popular movements will be improved in order to gather the Ummah under one roof in the world. It is clearly stated that the struggle will continue until all the oppressed/persecuted peoples are saved. Article 11 of the Constitution obliges the Islamic peoples of the Islamic Republic of Iran to provide political, economic, and cultural unity. The issue of protection of the oppressed is stated in Article 154 of the Constitution that except for the claims of the oppressed, the internal affairs of other nations will not be interfered. In the first idealist/romantic discourse of the revolution, Khomeini stated in a statement that he hoped to establish a party under the name of the Party of the Oppressed in the world (Humeyni, 1379, p. 185). Article 9 of the Constitution gives protection to the territorial integrity of Iran as the duty of the Islamic Republic of Iran as well as to each member of the nation. Article 153 of the Constitution includes the preservation of "independence and territorial integrity" among the foreign policy objectives of the Islamic Republic. The slogan "Neither the East nor the West, the Islamic Republic", which is the summary of Khomeini's foreign policy philosophy in the early years of the revolution, has been broken against geopolitical elements and realpolitik. The discussions on the meaning of this sloganized expression are excluded from our study (Muhammedi, 1377, p. 38).

\section{Understanding the Decision-Making Process in the Foreign Policy of the Islamic Republic of Iran}

Foreign policy decision-making approaches include system-level, global order/actor, individuals, groups, or non-state actors, such as the public. Here, we will briefly try to put forward the decision-making process in the Islamic Republic of Iran by trying to understand how the constitutional process works rather than the outcomes of the events. The highest political authority in the Islamic Republic of Iran is the Guidance Authority. Since Khomeini's vilayeti mutlak fakih is based on the concept of Fakih, there is no limit to his legal powers (Taflığlu, 2013). Article 110 of the Iranian Constitution gives some direct and indirect powers in the foreign policy decision-making process to leader (Rehber). First of all, it is the authority of the country to determine the general policy in consultation with the Assembly for the Determination of the Benefit of the Order and to check that it is implemented well. To give an example, when Egypt signed the Camp David Agreement with Israel, Khomeini cut diplomatic relations between Egypt and Iran with a fatwa. As the 
commander-in-chief of the Islamic Republic of Iran, the guide is entitled to declare war, peace, and mobilization. The decisions of the Supreme Council of National Security of the Islamic Republic of Iran cannot enter into force without the approval of the guide. The presidency is officially the second highest authority in Iran. According to Article 113 of the Constitution, the president is responsible for regulating the relations between the execution of the Constitution and the three powers (legislative, executive, and judicial). We will not enter into a controversial constitutional position of the president within the regime, but the issue that we must emphasize here is that in totalitarian regimes, the laws will not be read as written. Pursuant to Articles 113 and 133 of the Constitution, it authorizes the president to appoint his minister in charge of foreign policy. It has the authority to sign all agreements, covenants, and alliances on behalf of Iran (Article 125). It is up to the president to appoint Iranian ambassadors in other countries and to accept the ambassadors of other countries (Article 128). The Islamic Shura Assembly is an element of legislation (Article 171) (Taflıoglu, 2010). The Assembly of the Islamic Shura is an authority that has the power to ratify the signed international treaties, which are among the principal powers of all parliaments (Article 77). The border change agreement signed with any country shall be permitted if the interests of the country are respected and are not unilateral, without prejudice to independence and with the approval of $4 / 5$ of the Assembly of the Islamic Council (Article 78). In order to receive any foreign aid and lend to other countries, the approval of the Assembly of the Islamic Shura is required (Article 80). The approval of the Islamic Council is required to appoint foreign experts provided that it is non-military. As an important constitutional institution and a part of the legislative process, the Guardian Council has the authority to approve the decisions of the Assembly of the Islamic Shura and has an effective position in foreign policy decision-making (Article 94).

\section{A Brief Look at the Political History of Iranian-Egyptian Relations}

In narrow terms, Iran and Egypt are the two axis countries of the Middle East. Historically, the first contact of Iranians with Egypt was the Persian Empire that can be taken until B.C. 550. During the Fatimid period, Iran had one of the most powerful periods of cultural relations between Iran and Egypt (Yusufzade, 2019, p. 106). Naturally, this period coincided with the period when Azhar was established and Ismaili/Shiism became effective in Egypt. In 1869, the French government invited the Iranian Shah Nasreddin to the opening and sent a delegation to the Shah. In the same period, the presence of Cemalettin Esadabadi Afghani in Cairo and his scientific activities strengthened the cultural interaction between the two countries. In the 19th century, Egypt was bound to the Ottomans, albeit in shape, but in an effort to be autonomous and independent. Iran, on the other hand, was the most important country in the region for Egypt to receive political support against the Ottomans. The invasion of Egypt by the British Empire in 1881, the British Russian hegemony struggle over Iran, the constitutional movements of Iran were the most important problems of the two countries. Muhammad Reza Pahlavi's marriage to the sister of the Egyptian King Farouk made the two monarchies closer. The agreement between the British and Egyptian administrations in 1936 did not actually end the occupation, but it ended legally.

Turkey, Iran, Iraq, and Afghanistan signed Sadabad Pact. Although the Egyptian government had intention to join the agreement but the British and the German competition of that era did not permit. With the divorce of the Shah of Iran in 1948 from the sister of the Egyptian King, some coldness occurred between the two countries. The relations with the reign of the Mossadegh government in Iran and the reign of Abdul-Nasser in Egypt re-enacted. This process did not last long after the overthrow of Prime Minister Mossadegh with the Ajax 
operation organized by the US and British Intelligence in 1953, the two countries became distant from each other. Iran's entry into the Baghdad Pact and its close relationship with Israel brought tensions in Iranian relations with Egypt in 1960. Iranian Shah became the representative of Persian/Iranian nationalism. The 1967 Arab Israeli war dealt a major blow to Nasser's reputation, and Iran's support for the Arabs paved the way for the two countries to re-establish diplomatic relations. After the death of Nasser in 1970, Anwar Sadat came to power and the relations between Iran and Egypt were strengthened. Enver Sedat wanted to improve his relations with the US administration instead of the Union of Soviet Socialist Republics (USSR). The peace agreement he signed with Israel was the mainstay of this. The Shah of Iran supported the Sadat administration despite the opposition of other Arab states. Sedat, on the other hand, was in favor of keeping strong relations with Iran in the Persian Gulf against the Iraqi Baath administration.

After the revolution, Egypt lost its biggest supporter in the region against the other Arab states of its agreement with Israel. Khomeini cut diplomatic ties with Egypt with a fatwa and became the biggest enemy in the region. Naturally, the Egyptian government accused the Islamic Republic of intervening in the internal affairs of the Arab states and regarded it as a danger to their national security. Khomeini's rhetoric supported Egypt's discourse that Iran posed a danger to regime exports to Arab states, and that it was a major threat to Gulf Arab states in particular. With the start of the Iran-Iraq war, the Egyptian administration had the opportunity to re-develop its relations with the Arab states by providing military and economic support to Iraq. With the establishment of a ceasefire between Iran and Iraq, the Iranian administration delivered Egyptian prisoners as demonstrations of goodwill. Iran began to normalize its relations with Arab states, especially Saudi Arabia, in the period that it called the post-war economic structure. The disintegration of the USSR, the invasion of Iraq by Kuwait, the peace agreements between the PLO-Israel and Jordan were the factors that paved the way for the softening of Iran's relations with the countries of the region. Muhammad Khatami's election as president and moderate rhetoric helped to improve relations with the Gulf countries and the European Union. While Iran wanted to improve its relations with other Islamic countries through the Organization of Islamic Conference, it established cultural and economic relations with Egypt. The activities on the subject of Persian language education in Cairo are the leading ones. Egypt established a factory in Iran and Iran started to sell tractors to Egypt. However, the global and regional developments, the ideological structure and activities of the Islamic Republic of Iran, and the complexity of foreign policy decision-making prevented the full development of relations with Egypt.

\section{Post-2011 Iran-Egypt Relations}

With the blessing of the Mubarak regime, Iran expected a new chapter in relations with Egypt. Most Iranian thinkers and experts argued that this was a revolution. Guide Khamenei advised the Egyptian army to stand by the people in his Friday sermon in Arabic in February (Muhammed \& Mahmud, 2016). Iran's Foreign Minister, on the other hand, supported the cheering of the Egyptian people and heralded the birth of an Islamic Middle East. Former President Rafsanjani told a newspaper he called on the people to continue their actions and told Egypt that a leader like Khomeini is now a must. At that time, Iranian President Ahmedi Nejat declared in his statements that the Middle East would soon be dried from America and Israel. In one statement, he even claimed that Imam Mahdi had the hand in these popular movements. Former President Khatami spoke of the great contribution Iran and Egypt made to Islamic civilization, and that Egypt had been the center of the anti-exploitation struggle for the last 150 years. 
Naturally, the expectation was a serious break in the foreign policy of Iran after the revolution. Unless the geography of a country changes, its existential foreign policy based on geopolitical realities is unlikely to change. The real issue was how much Egyptian foreign policy could change after January 2011. Accordingly, would this change be reflected in relations with Iran? While the process was ongoing, an Iranian diplomat was declared unwelcome on 30 May, 2011 for espionage and was asked to leave Egypt. During the presidency of Morsi, in August 2012, a commission including Iran, Egypt, and Saudi Arabia was proposed to solve the Syrian problem. Mursi was the first and only president to visit Iran after the revolution. The policy of the Morsi administration against the Syrian government was not the same as that of the Iranian government. The common ground of both countries was that North Atlantic Treaty Organization (NATO) and all foreign armed elements must leave Syria. In October of the same year, the Iranian Egyptian Businessmen forum was held in Tehran and the Egyptian delegation discussed military cooperation with the Iranian deputy defense minister. In 2013, Iranian President Ahmedi Nejad visited Cairo with his foreign minister and expressed his wish to improve relations with Egypt to an unlimited extent. But in order to welcome him, the Sheikh of Azhar, who was very far from Iran, also joined. The Morsi administration did not agree in every issue implicitly with Iran, especially on the Syrian issue. The Gulf Arab countries, especially Saudi Arabia, which had a great importance for the Egyptian economy, did not want Egypt to get closer to Iran.

\section{Post-Mursi Relations}

The first statement made by the Iranian foreign spokesman was that everything was not over, that the movement continued and that the army should not enter politics. A spokesman for the Egyptian foreign affairs declared that they saw this as an intervention in their internal affairs and that they could not accept it. The new administration was inviting the Iranian president to attend the sworn-in ceremony of Sisi, the Egyptian president, in fact making a gesture to Iran and looking for a leverage to strengthen his legitimacy. Although he did not respond to the spiritual invitation, the Iranian deputy foreign minister, responsible for Arab and African affairs, participated. The deputy foreign minister said Egypt's security is Iran's security, and Egypt is stronger in Iran (Osman, 2014). The visit of the Emir of Kuwait to Iran and the meeting with the guide and President Rouhani was an important indicator for Egypt. Egyptian President Sisi stated in a statement that relations with Iran have passed through the Persian Gulf (Basra) and that Egypt's security cannot be separated from Gulf security (Ebu'l-az, 2014). Iran has made it clear that it wants to develop relations with the new administration by declaring that we respect the preferences of the Egyptian people. After 30 June 2013, the Egyptian Minister of Foreign Affairs declared in a statement about Egypt's priorities in foreign policy that they did not see Iran as an enemy, but the Muslim Brotherhood representing political Islam as the biggest enemy (Muhammed \& Mahmud, 2016). On the other hand, in July 2015, Iran declared Egypt among the nationals who will travel to Iran without a visa. The Egyptian administration has declared that Iran has the right to benefit from nuclear energy for peaceful purposes (Bahi, 2015). In 2016, the attacks on the embassies and consulates of Saudi Arabia in Iran were strongly condemned by Egypt due to the harsh intervention of the Saudi Arabian administration against the Iranian pilgrims. The Sisi administration has clearly demonstrated its support for Saudi Arabia and its weak relations with Iran.

Although Iran has declared that they want to sell oil to Egypt many times, Iran has been excluded from this issue with the stimulation of Saudi Arabia. Egyptian Foreign Minister Samih Şükri explained that the basic condition for establishing a dialogue with Iran should not interfere in the internal affairs of the Arab states and 
try to dominate them (Alwasatnews, 2017). Upon reports of Iranian weapons capture in Yemen, the Egyptian administration described Iran as an open continuation of its involvement in the internal affairs of neighboring Arab states (Aljazeera, 2016).

\section{Geopolitical Parameters and Political Activities that Prevent Cooperation}

Throughout history, relations between Iran and Arab states have developed at the center of the shadow of the concepts of Arab-Persian/Shi'ism. Regardless of the discourse of Iranian foreign policy, Iran could not elude the Safavid/Sassanid/Zoroastrian title in the eyes of the Arab states. In global politics, states perceive and act as a whole with their geography. History is an inseparable part of geography and of course states. It will always carry this past on its back in its relations with Egypt. Shiite geopolitics is one of the most fundamental and decisive geopolitical parameter of Iranian foreign policy. For Iran, the nature of the regime does not change this situation, which is also a realpolitik reality. Egypt is one of the countries that have the strongest military and economic relations with the American administration in the region. Egypt is one of the countries that get the highest financial and military aid directly from the United States each year. Egypt's strong relationship with the United States is an obstacle to establish a real political and economic relationship between Iran and Egypt.

Iran seeks to besiege Israel in the Red Sea and the Nile Basin, seeking an exit base from the Persian Gulf. Iran's African expansion goes back to the 1960s during the Shah period. The newly independent African countries and the Shah administration carried out their diplomatic activities in the 1970s with the increase in oil revenues and the support of the American administration to prevent the spread of the Soviets and Communism on the African continent. After the revolution, Khomeini described the peoples on the African continent as oppressed and US and Soviets as evil forces and oppressors. Due to the chaos and the Iraq war in the early years of the revolution, Iran could not show enough attention to the African continent in its foreign policy. During the end of the war and the economic restructure of the Rafsanjani period after Khomeini, Iran's foreign policy entered into more constructive discourses against Arab states. In this context, Rafsanjani made his first visit to Sudan in 1991. Military and economic agreements with mutual obligations were signed between the two countries (EPC, 2016). In 1996, Rafsancani took a comprehensive trip to Africa, including African states, such as South Africa, Kenya, and Tanzania, with senior bureaucrats and businessmen. During the Khatami period, political and diplomatic attention was paid to the African continent as an observer member of the African Union Organization. There were allegations that the Iranian Revolutionary Guards used some of Sudan's coastal ports to send arms to some armed movements in Gaza and Africa (The Times of Israel, 2014).

One of the most disturbing issues of the Egyptian government is the military and intelligence activities of the Iranian Revolutionary Guards in the Red Sea. In 2014, the Israeli army claimed to have found Iranian weapons on a Panama-banded ship on the Red Sea (Ynetnews, 2014). A large number of explosives were seized on a ship caught off the coast of Yemen, and the possibility of these weapons going to Somalia by the intelligence circles came to the region (Charbonneau \& Nichols, 2013). The Egyptian administration considers being Sudan and Somalia as Iran's backyard unacceptable for its own national security. Iran sees Sudan and Somalia as the gateway to Africa and a siege to Israel and a ramp to support Palestinian armed resistance organizations, such as Hamas and Islamic Jihad. Egypt, on the other hand, takes an attitude against Iran in all international settings on issues such as the three islands of the United Arab Emirates with Iran. Egypt wants the Iranian administration to hand over the members of the organization, such as the Islamic and Jihad of the Jamaat, which it has captured in its country or region. Iran, on the other hand, appeals and condemns the 
captured armed resisters.

\section{Possible Areas of Cooperation}

The best places to develop cooperation for Iran and Egypt seem to be the activities and meetings of international organizations such as the UN, G8, G15, and the Organization for Islamic Cooperation. In particular, Iran is in deep need of diplomatic support from global and regional organization states in the nuclear energy issue. Such global and regional diplomatic organizations provide a good basis for influencing the world and regional public opinion. Israel's possession of a large number of nuclear weapons could create another ground for diplomatic cooperation with Iran. For many years, Egypt has been carrying out diplomatic activities in diplomatic environments in order to demilitarize the Middle East and to sign Israel's NPT treaty. In this policy context, a natural alliance with Iran, which has the same policy in all international environments, arises. Although Egypt withdrew from the Sinai Peninsula, the Taba region is still a serious problem between Israel and Egypt. Israel must pay a substantial amount for the natural gas and resources it uses during the years it occupied. The issue of the Israeli administration and the problem of Egyptian prisoners and citizens in Israeli prisons are the issues that Iran will support.

Like Iran, Israel is building military, political, and economic relations with many African countries, such as Kenya and Ethiopia. It is a complex and controversial issue which poses more threats as it threatens if Egypt chooses between Israel and Iran. It is a well-known fact that Israel has used African Jews for intelligence since its inception. Especially in the water problem between Egypt and Ethiopia, Israel is technologically and economically related to Ethiopia. Iran could be a balance for Egypt against the power and siege of Israel in Africa. In the same way, Iran may be a serious partner in the field against the Egyptian and regional leaders who are seen as the biggest threat to the Egyptian administration. The issue of the establishment of the Palestinian state meets the same point of Egypt and Iran. Cooperation in terms of intelligence against Israel is a possible area of cooperation between other Egypt and Iran.

\section{Conclusion}

Although the relations between Iran and Egypt seem to have converged for a short period after 2011, it is not possible to say that there is a serious relationship between the two countries. Iran wants to pursue a more balanced policy instead of a conflictual policy with Egypt and Saudi Arabia in the face of increasing US presence and pressure in the region. Saudi Arabia and the Gulf Arab states see America and Egypt as a counterbalance to Iran's growing military and ideological power in the region. Iran's geopolitical superiority in the region makes it essential for Arab states to cooperate with countries, such as America and Egypt. The main discourse of Iran's regional politics is based on the removal of the region from the foreign military presence, which is shown as the source of the problems. According to this argument, the relations between Iran and Arab countries will settle on a mutually healthier basis. It is unlikely that states, such as Saudi Arabia and the Gulf States, especially the US, who are weak against Iran without external support, will be able to accept this offer. Saudi Arabia,s direct oil and financial aid as soon as the Sisi administration arrived in Egypt stems from the need for Egypt versus Iran. Iran, as far as possible, wants to try to keep its discourses against America and relations with the states in the region separate. Given the American political relations with Egypt and Saudi Arabia and its military presence in the Middle East, this is hardly possible in practice.

Iran thinks it can be more effective on Arab states if it can improve political and cultural relations with 
Egypt. Egypt, on the other hand, sees Iran as a threat not only to the Gulf states. Egypt closely follows the political, military, economic, and ideological activities of Iran in Africa and the Nile Basin. Egypt sees Iran's settlement as a vital threat in and around the Red Sea, which it regards as vital to its national security. Iran sees military and political expansion into the Red Sea and its watershed as a strategic move for its foreign policy.

\section{References}

Aljazeera. (2016). Misr munza'acat l'istimrar Iran bitehrib Eslihat lil'Yemen. Retrieved February 10, 2019, from https://www.aljazeera.net/news/arabic/2016/4/7

Alwasatnews. (2017). La mecal haliyen ey hivar ma'a Iran. Retrieved February 11, 2019, from http://www.alwasatnews.com/news/1096973.html

Bahi, R. (2015). Elittifaku'l-Neveviyu'l-İrani ved'duru'ul-İklimi li'Misr. Retrieved February 19, 2019, from https://drive.google.com/file/d/OB9mwL5_FZOYJdHMxQ2RvOGFpR2c/view

Charbonneau, L., \& Nichols, M. (2013). Arms ship seized by Yemen may have been Somalia-bound-U.N. Retrieved February 10, 2019, from https://uk.reuters.com/article/uk-somalia-arms-un-idUKBRE96101420130702

Ebu'l-az, İ. (2014). Delalat Dav'et Ruhani Li'l-Kahire ve Afk'ul-Alakatu'l-Misr-el-İraniye fi ahd “Essisi”. Retrieved February 11, 2019, from https://elbadil.com

EPC. (2016). Ennufuzü'l-Irran fi'l afrika el'muhadadat ve'laliyatu'l-ihtirak. Retrieved February 10, 2019, from http://www.epc.ae/ar/publication/irans-influence-in-africa-determinants-and-mechanisms

Humeyni, İ. (1379). Sahifeyi Nur (Vol. 9). Teheran: Müessesy-i Tanzim ve Neşr-i Asar-1 İmam Humeyni.

Muhammed, A. A., \& Mahmud, D. (2016). Elalakatu'l Misr-El-Iraniye min Fetret “2011-2016”. Retrieved February 10, 2019, from https://democraticac.de/?p=35024

Muhammedi, M. M. (1377). Ber Siyaset-i Harici Cumhuri Iran Devran-ı Pehlevi. Teheran: Neşri Dadgöster.

Osman, M. (2014). Iran Tera Mustekbala ve İada Li'i-alakat Ma Misr. Retrieved February 19, 2019, from http://www.ahram.org.eg/NewsQ/301322.aspx

Taflıoğlu, M. S. (2010). Humeyni İran İslam Devrimi. Ankara: Kripto.

Taflığlu, M. S. (2013). İran İslam Cumhuriyeti'nde Egemenlik ve Meşruiyet Kaynağ 1 "VELÂYET-İ FAKİH”. Ankara Üniversitesi SBF Dergisi, 68(3), 95-112.

The Times of Israel. (2014). Iranian warships dock at Port Sudan. Retrieved February 10, 2019, from https://www.timesofisrael.com/iranian-warships-dock-at-port-sudan/

Ynetnews. (2014). UN experts trace Klos C arms ship to Iran. Retrieved February 10, 2019, from https://www.ynetnews.com/articles/0.7340.L-4535391.00.html

Yusufzade, İ. (2019). Revabıtı Docanebi İran ve Misr Fırsatha, Çaleşha ve Çeşmendazi Ayende. Retrieved February 10, 2019, from http://ensani.ir/file/download/article/20120325202005 1149-182.pdf 